\title{
Migration characteristics of long-tailed ducks (Clangula hyemalis) from the western Canadian Arctic
}

\author{
Blake A. Bartzen ${ }^{1}$ (i) $\cdot$ D. Lynne Dickson ${ }^{2}$ Timothy D. Bowman ${ }^{3}$
}

Received: 22 February 2016/Revised: 26 July 2016/Accepted: 12 September 2016/Published online: 3 October 2016

(C) The Author(s) 2016. This article is published with open access at Springerlink.com

\begin{abstract}
There are significant deposits of oil and gas in the Beaufort and Chukchi Seas, and many long-tailed ducks (Clangula hyemalis) spend a large portion of their annual cycle in that region, but little is known about their migration patterns. Consequently, we used satellite telemetry to track movements and reveal migration routes and staging areas of 57 long-tailed ducks from the western Canadian Arctic. After molting, all ducks moved westward along the Beaufort Sea coast of Canada and Alaska, into the Chukchi and Bering Seas and the North Pacific, staging at various locations. Long-tailed ducks wintered throughout the North Pacific region as far south as British Columbia, Canada on the North American side and Japan and South Korea on the Asian side, a distribution similar to long-tailed ducks marked with transmitters in Alaska. Spring migration of long-tailed ducks was generally a reversal of fall migration, following Alaskan and Asian coastlines north and eastward to breeding areas in Northwest Territories, Canada, with the exception of two females that travelled to Russia and one male and one female that stopped in northwestern Alaska for the breeding period. Migratory patterns of ducks from this study displayed both similarities and variations to other species breeding in the Arctic, e.g., eiders. However, similar to eiders, long-tailed ducks were in or near offshore oil and gas lease areas of the
\end{abstract}

Blake A. Bartzen

blake.bartzen@canada.ca

1 Canadian Wildlife Service, Prairie and Northern Wildlife Research Center, 115 Perimeter Road, Saskatoon, SK S7N 0X4, Canada

253442 Range Road 222, Ardrossan, AB T6B 2X3, Canada

3 U.S. Fish and Wildlife Service, 1011 East Tudor Road, Anchorage, AK 99503, USA
Beaufort and Chukchi Seas for significant portions of their annual life cycle, making them vulnerable to impacts from exploration and development in that region.

Keywords Clangula hyemalis · Long-tailed duck · Migration · Oil and gas · Satellite telemetry $\cdot$ Staging areas

\section{Introduction}

The Arctic may undergo significant change in the coming decades through environmental and anthropogenic pressures. Many alterations could result from climate change, including changes in species composition, coastal erosion, changing patterns of weather and ocean currents, sea-level rise, and variable but reduced extent of sea ice (Hinzman et al. 2005). In addition, there will likely be increased shipping traffic and development associated with resource extraction (Gautier et al. 2009; Corbett et al. 2010). There are large deposits of oil and gas in the Arctic, much of it offshore, that are currently, or could potentially be, developed for extraction (Gautier et al. 2009; Zabanbark and Lobkovsky 2015). The Arctic remains an important breeding area for many migratory bird species, which could be significantly affected by changes to the Arctic environment through timing mismatches (e.g., hatch of young no longer coincides with emergence of principle food sources (Dickey et al. 2008; McKinnon et al. 2012), changes in predator-prey communities, alterations to habitat, increased disturbance from human activity, and catastrophic events such as oil spills or extreme weather events (Chapin et al. 1995; Visser and Both 2005; Dickson and Smith 2013; Nolet et al. 2013). Understanding the risks to migratory bird populations in the Arctic can be a challenge because it is remote and inaccessible but also because 
most species breeding in the Arctic migrate long distances and spend most of the non-breeding season at more southern latitudes.

Migratory connectivity, the links between breeding and non-breeding areas, has implications for ecology, evolution, conservation, and management of species (Webster et al. 2002). Studying annual migration patterns can reveal critical areas and habitats, help to identify distinct populations and subpopulations, and may provide insights into potential threats and limiting factors to populations. For birds that migrate long distances, especially those that spend all or part of their lives in remote locations such as the Arctic, migratory connectivity can be difficult to ascertain. However, recent technological advances in genetic and isotope analysis, and remote tracking, such as satellite telemetry, have vastly improved our understanding of migratory patterns of many species (Webster et al. 2002; de la Cruz et al. 2009; Bridge et al. 2015). For example, until recently, little was known about migration routes, timing, and the links between breeding and winter locations of eiders, but with the use of satellite telemetry, our understanding of their migration ecology has vastly improved (Petersen et al. 1999; Phillips et al. 2006; Oppel et al. 2008; Dickson 2012a, b).

Long-tailed ducks (Clangula hyemalis) breed in the circumpolar Arctic and migrate to cold, temperate waters (primarily coastal) for the non-breeding period (Robertson and Savard 2002). As with several other sea duck species, long-tailed ducks have experienced significant long-term population declines for unknown reasons, and the ecology of long-tailed ducks remains poorly understood relative to other waterfowl (Dickson and Gilchrist 2002; Flint 2013; Bowman et al. 2015). Previous surveys and studies indicated that the western Canadian Arctic is an important area for breeding and molting long-tailed ducks (Alexander et al. 1988; Dickson and Gilchrist 2002; Latour et al. 2008), but until this study, only three satellite transmitters had been successfully deployed on long-tailed ducks in that region (Dickson unpublished data). Consequently, little was known about migration corridors, staging areas, and winter locations for long-tailed ducks that breed in the western Canadian Arctic. If offshore oil and gas exploration and development should continue in the Arctic, there is a possibility that long-tailed ducks could be adversely affected through loss or alteration of habitat, disturbance, disorientation from or collision with offshore structures, and contamination from oil spills or other pollutants (Lacroix et al. 2003; Dickson and Smith 2013; Day et al. 2015).

Therefore, the objectives of this study were to characterize the spatiotemporal use of habitat throughout the year, including periods of migration, to better understand the annual requirements of long-tailed ducks, and to evaluate potential risks from oil and gas development. Specifically, we wished to determine (1) migration routes and wintering areas, (2) whether long-tailed ducks used similar staging areas during fall and spring migration, (3) whether there was fidelity to wintering and molting areas, and (4) whether areas utilized by long-tailed ducks overlapped with potential oil and gas development areas. Based on migration data for the three previously marked long-tailed ducks, as well as king eiders (Somateria spectabilis) and common eiders (Somateria mollisima) breeding in the western Canadian Arctic (Dickson 2012a, b), we expected longtailed ducks from the western Canadian Arctic to migrate through the Beaufort and Chukchi Seas and winter in areas along the coasts of northeastern Asia and northwestern North America. As ice and open-water conditions vary markedly between spring and fall in the Arctic, we predicted that long-tailed ducks would use some different staging areas during migration to and from breeding areas in the Arctic (Dickson and Gilchrist 2002; Oppel et al. 2009; Dickson and Smith 2013). Sea ducks, in general, tend to show a high degree of fidelity to migration routes and areas used during their annual life cycle, so we expected that long-tailed ducks would, likewise, display a high degree of fidelity (Greenwood 1980; Savard and Eadie 1989; Smith et al. 2000). Finally, if long-tailed ducks moved through the Beaufort and Chukchi Seas as we predicted, we expected the areas used by long-tailed ducks would overlap with areas of existing and potential oil and gas development, similar to other sea duck species (Oppel et al. 2009; Dickson and Smith 2013).

\section{Materials and methods}

\section{Satellite telemetry}

Flightless molting long-tailed ducks were captured at McKinley Bay, Northwest Territories, Canada $\left(69^{\circ} 56^{\prime} \mathrm{N}\right.$, $131^{\circ} 08^{\prime} \mathrm{W}$; Fig. 1), from early to mid-August in 2009 and 2010. We used three to five motorized boats and kayaks to drive the birds toward a floating, lightly weighted, monofilament gillnet ranging in length from 150 to 300 feet and 10 feet in depth (Breault and Cheng 1990). As birds neared the net, we rushed toward them and made loud noises, causing them to dive and become entangled in the suspended net. We quickly untangled ducks from the net and placed them in small kennels for transport to a field camp nearby.

Each bird was equipped with a satellite transmitter (26 g platform terminal transmitter with external whip antenna; Microwave Telemetry Inc., Columbia, Maryland) following surgical methods described by Korschgen et al. (1996) and Mulcahy and Esler (1999). Transmitters were implanted in 


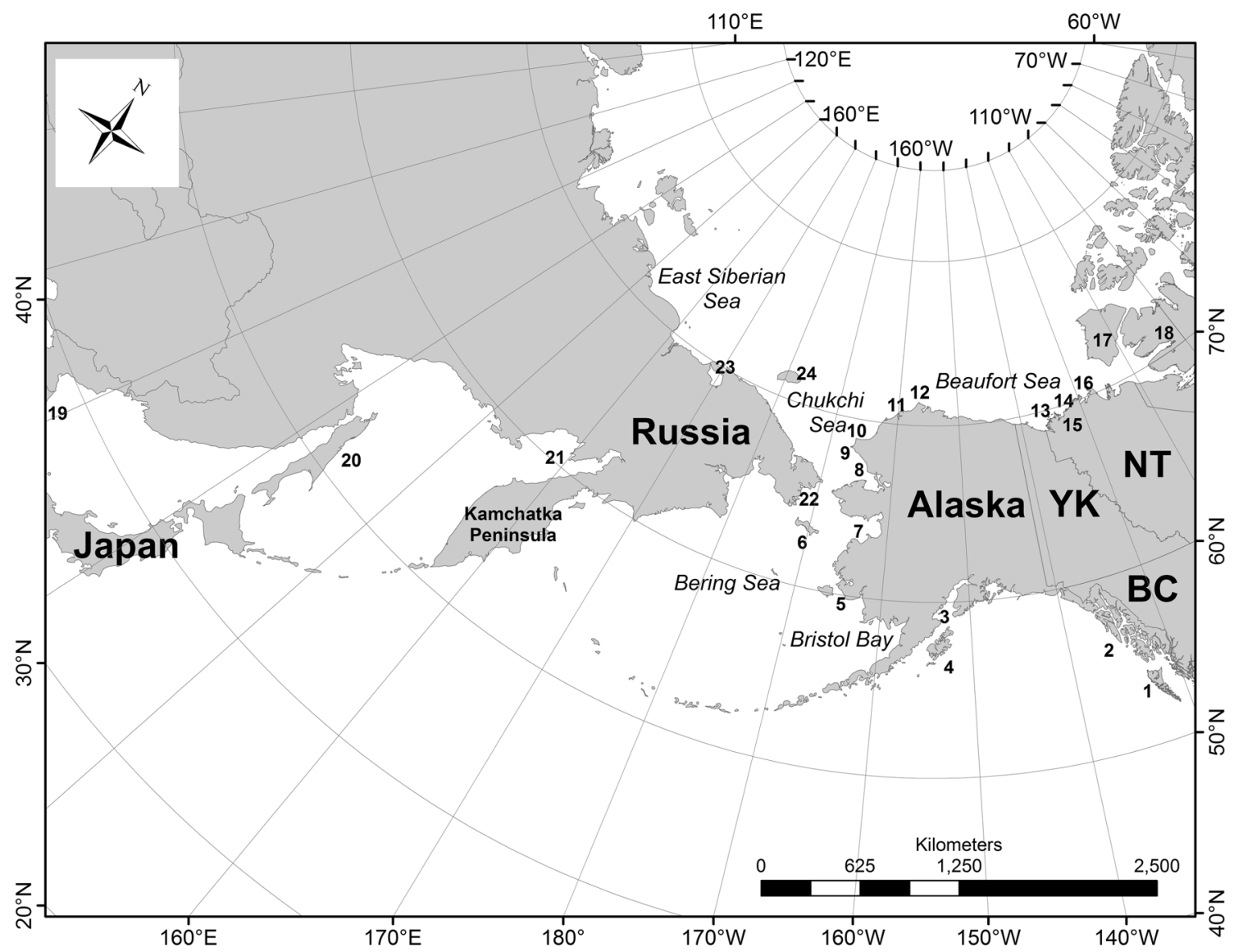

Fig. 1 Key places mentioned in this paper. NT Northwest Territories, $Y K$ Yukon, $B C$ British Columbia, 1 Haida Gwaii Archipelago, 2 Alaska Panhandle, 3 Cook Inlet, 4 Kodiak Island, 5 Nunivak Island and Yukon-Kuskokwim Delta; 6 St. Lawrence Island, 7 Norton Sound, 8 Kotzebue Sound, 9 Point Hope, 10 Cape Lisburne, 11 Peard

the abdominal cavity, and the antennas exited through the caudal abdominal wall with antennas pointing skyward outside of the bird (Korschgen et al. 1996). Sex and age of birds were determined by measuring bursal depths and examining plumage characteristics (Mather and Esler 1999). Transmitters were programmed with variable transmission cycles (period when data are being transmitted followed by period of no transmission) to transmit more frequently during migration periods (Table 1); we used
Bay, 12 Point Barrow, 13 Mackenzie River Delta, 14 Tuktoyaktuk Peninsula and McKinley Bay (capture site), 15 Husky Lakes, 16 Cape Bathurst, 17 Banks Island, 18 Victoria Island, 19 South Korea, 20 Sakahalin Island, 21 Gulf of Shelikhov, 22 Chukotka Peninsula, 23 Chaunskaya Bay, 24 Wrangel Island

transmission cycles that would help ensure transmitters provided location data for an entire annual cycle. Argos (CLS America, Lanham, Maryland) provided location data, and we filtered data to omit unlikely locations using the Douglas Argos-Filter Algorithm (Douglas et al. 2012). Transmitters provided information on location, location accuracy, temperature, and battery voltage. A significant drop in temperature was an indication of bird mortality, and a drop in voltage was an indication that transmitter batteries
Table 1 Transmission cycles of $26 \mathrm{~g}$ satellite transmitters (platform terminal transmitters) implanted in long-tailed ducks (Clangula hyemalis) at McKinley Bay, Northwest Territories, Canada, in 2009 and 2010

\begin{tabular}{|c|c|c|c|c|c|c|}
\hline \multirow[t]{3}{*}{ Period } & \multirow{2}{*}{\multicolumn{2}{|c|}{$\frac{2009 \text { transmitters }}{(n=25)}$}} & \multicolumn{4}{|c|}{2010 transmitters } \\
\hline & & & \multicolumn{2}{|c|}{$(n=16)$} & \multicolumn{2}{|c|}{$(n=17)$} \\
\hline & On & Off & On & Off & On & Off \\
\hline August to mid-December & 2 & 48 & 2 & 72 & 3 & 72 \\
\hline Mid-December to late March & 2 & 120 & 4 & 96 & 3 & 72 \\
\hline Late March to early August & 3 & 48 & 4 & 72 & 3 & 72 \\
\hline Early August to last transmission & 2 & 72 & 4 & 72 & 3 & 72 \\
\hline
\end{tabular}

$\mathrm{ON}$ is the number of hours transmitting per cycle, and OFF is the number of hours off per cycle 
were losing power. We used ArcMap 10.1 (Environmental Systems Research Institute, 2012, Redlands, CA-http:// www.esri.com) to process and map the filtered location data. After the data were filtered for unlikely locations, $78 \%$ of the locations had an accuracy $\leq 1500 \mathrm{~m}$, and $30 \%$ of the locations had an accuracy of $<250 \mathrm{~m}$. In instances when location accuracy was either $>1500 \mathrm{~m}$ or incalculable and thus not reported, locations before and after were examined to determine the plausibility of the location of concern. If we deemed a location implausible, it was removed from subsequent analyses.

We equipped 23 females and two males from August 4-9, 2009, and 22 females and 11 males from August $6-17,2010$, with transmitters; all birds were adults. Body mass of the ducks implanted with transmitters was $713 \pm 70 \mathrm{~g}$ (standard deviation), and there was no difference between males and females $(t=-0.0547$, $d f=14.1810, P=0.9571)$; therefore, transmitters were roughly $4 \%$ of the body mass of the birds. Females were preferentially tagged because they provide less ambiguous indications of breeding than do males, and we predicted they would return to the western Canadian Arctic the following spring, thus providing information on spring migration through the Beaufort and Chukchi Seas. Males, which may pair with females from throughout the breeding range, including Alaska and Russia, were less likely to return to breeding areas in western Canada and provide information on use of Beaufort and Chukchi Seas (Greenwood 1980; Smith et al. 2000). However, we tagged more males in 2010 due to difficulty in capturing females that year. We detected mortality (i.e., low-temperature signals) for three birds: one bird tagged in 2010 died $<12$ days after surgery, one bird tagged in 2009 died between 60 and 85 days after surgery during fall migration, and one bird tagged in 2010 died during the following winter between 153 and 172 days after surgery. Many of the transmitters we deployed in 2009 ceased transmitting location data earlier than we predicted, and there was no clear evidence why this occurred. Consequently, we worked closely with Microwave Telemetry Inc., in the winter of 2009 and 2010 to choose transmission cycles that would lengthen the duration of life of the transmitter batteries (Table 1). Despite these alterations to the transmission cycles, we found no significant differences between years in the duration that transmitters provided location data (Mann-Whitney-Wilcoxon $W=419.5, P=0.425, n=55)$; the three birds with known mortality were excluded from this analysis. The median duration for transmitting was 169 days (minimum $=33$ days; maximum $=566$ days $) ; 12$ transmitters lasted $>320$ days (roughly the onset of the breeding season in the following year) and eight transmitters lasted $>365$ days.

\section{Definitions of migratory periods}

We characterized the annual cycle of long-tailed ducks for the following seasons: molt, fall migration, winter, spring migration, breeding, and molt migration, consistent with terminology used in other studies of sea ducks breeding in the Arctic (Petersen and Flint 2002; Oppel et al. 2008). We defined the onset of fall migration as the first directional movement from McKinley Bay, the molting area where we captured the ducks; initial movements were typically $>50 \mathrm{~km}$ as defined by Petersen and Flint (2002), but that was not the case for all birds. We defined ducks' arrival at winter locations as the first of a series of locations consistently $<50 \mathrm{~km}$ apart following the lengthier movements of fall migration. We defined the onset of spring migration as the first movement $>50 \mathrm{~km}$ northward after the relatively stationary winter period. We assumed that breeding had commenced for females once they were inland and relatively stationary, i.e., subsequent locations were $<10 \mathrm{~km}$ apart; males were not used to determine breeding locations. Molt migration commenced when birds left the breeding location and ceased when birds arrived at the molt location. In the few instances when the molt location was not McKinley Bay in the year after marking, we identified the molt location as the area where birds were located for $>28$ days between mid- to late July and most of August and the distance between locations was $<20 \mathrm{~km}$ (Guillemette et al. 2007). Distances travelled during migratory periods were calculated by summing the distances between locations for the respective periods but should be considered minimum distances as ducks did not travel in a straight line between points.

\section{Calculation of season durations and dates of onset}

For each duck, we determined the date of onset of each season as the first date it exhibited the aforementioned behavior. Because we did not receive location data every day, the onset dates presented are likely one to 10 days later than when an actual event first took place and should be considered conservative. We calculated the duration of migratory periods as the first known date at an arrival location minus last known date at a departure location minus length of one transmission cycle. For stationary periods, we calculated the total duration of stay as the number of days between first and last locations plus the length of 1 transmission cycle. Birds with transmitters that did not provide location data more frequently than 11 days during the transitions between seasons were excluded from calculations of onset dates and duration of seasons. We used data from birds with transmitters that were functional for $>365$ days to examine site fidelity to molt and winter sites, but the second-year data were not used in calculations 
of season onset and duration because of a lack of independence. We calculated distances between winter locations for birds with second-winter data by first generating a center location for each year of winter locations using the mean center tool in ArcMap and then measuring the distances between the two centers.

\section{Spatial characterization of staging and wintering areas}

To calculate the area each individual used during staging and winter, we used $95 \%$ volume contours of kernel density estimates calculated in Geospatial Modelling Environment (Beyer 2012). We delineated staging and winter areas using the same technique: We used the Gaussian kernel function with the plug-in bandwidth estimator and a cell size of $10,000 \mathrm{~m}^{2}$. Following Petersen and Flint (2002), we defined staging locations as areas where one or more individuals spent (i.e., moved $\leq 50 \mathrm{~km}$ between consecutive locations) more than 7 days during migration.

\section{Movements in relation to oil and gas lease areas}

Because a key objective of the study was to evaluate potential risk of offshore oil and gas development activities to long-tailed ducks, we examined the movements and staging areas of ducks spatially in relation to oil and gas leases in the Beaufort and Chukchi Seas. We accessed information on exploration and significant discovery leases from the Government of Canada (2013), and from State of Alaska (2013) and US Government Web sites (Bureau of Ocean Energy Management 2013).

\section{Results}

Males departed molt sites earlier than females in 2010 (Mann-Whitney-Wilcoxon $W=175, P=0.02, n=32$ ), but there were no significant differences between sexes for the dates and durations for winter and spring migration $(P>0.25)$. We did not test for differences between sexes for birds tagged in 2009 because we only tagged two males in that year and one of the males was a bird that died during fall migration. We found no statistical differences between years in dates or durations of seasons $(P \geq 0.15)$. Because there were no significant differences between sexes for all but commencement of fall migration and there were no significant differences between years, subsequent results are based on the data pooled for years and sexes with the exception of fall migration. Unless stated otherwise, results are reported as mean \pm standard deviation.

\section{Fall migration}

Male long-tailed ducks departed the molting area at McKinley Bay on September $10 \pm 9$ days $(n=13)$, and females departed on September $21 \pm 11$ days $(n=44)$. All birds followed the Beaufort Sea coastline of Canada and Alaska westward into the eastern Chukchi Sea (Fig. 2). As birds reached the southern Chukchi Sea, some branched off travelling southwest along the Asian coastline and the others travelled southward along the Alaskan coastline (Fig. 2). On the North American side of the North Pacific, ducks migrated as far south as the Haida Gwaii archipelago, British Columbia, Canada, and on the Asian side, birds travelled as far south as Japan and South Korea (Figs. 2, 3). One male actually migrated westward along the north Siberian coast and staged just east of Chaunskaya Bay, Russia, before migrating to the Gulf of Shelikhov, Russia.

Birds staged at several locations along the fall migration route (Fig. 2). The area offshore of the Tuktoyaktuk Peninsula and Mackenzie River Delta in the Canadian Beaufort Sea was the first major staging area for long-tailed ducks that molted at McKinley Bay; 24 individuals (42\% of all functioning transmitters) staged there, arriving September $13 \pm 11$ days and departing October $1 \pm 11$ days. Another 17 individuals used the area but stayed there $<7$ days, hence did not meet the criteria for staging. There were two main areas in the Beaufort and Chukchi Seas along the Alaskan north coast where 10 individuals (18\% of all functioning transmitters) staged, arriving September $18 \pm 12$ days and departing October $3 \pm 12$ days; 19 additional individuals were detected in these areas but did not stage. The next major staging area to the west was the east coast of the Chukotka Peninsula, Russia, where 24 individuals (44\% of all functioning transmitters) staged and another seven individuals travelled through but did not stage. Birds that staged off the Chukotka Peninsula arrived on October $5 \pm 8$ days and departed October $30 \pm 11$ days. Five individuals (9\% of all functioning transmitters) staged nearby at St. Lawrence Island, Alaska, arriving October $12 \pm 14$ days and departing November $7 \pm 16$ days; two additional individuals did travel through the area. Twelve individuals (23\% of all functioning transmitters) staged south of Nunivak Island, YukonKuskokwim Delta, and in the Bristol Bay area of Alaska, arriving October $22 \pm 12$ days and departing November $21 \pm 14$ days; two additional individuals travelled through the area. Other individuals staged at Kodiak Island, the Alaska panhandle, and Haida Gwaii on the North American side, and Kamchatka Peninsula and Sakhalin Island in Russia. Fall migration lasted $52 \pm 24$ days for females $(n=21)$ and $73 \pm 28$ for males $(n=6)$. Average distance travelled was $3293 \pm 1324 \mathrm{~km}(n=35$; Table 2$)$. 


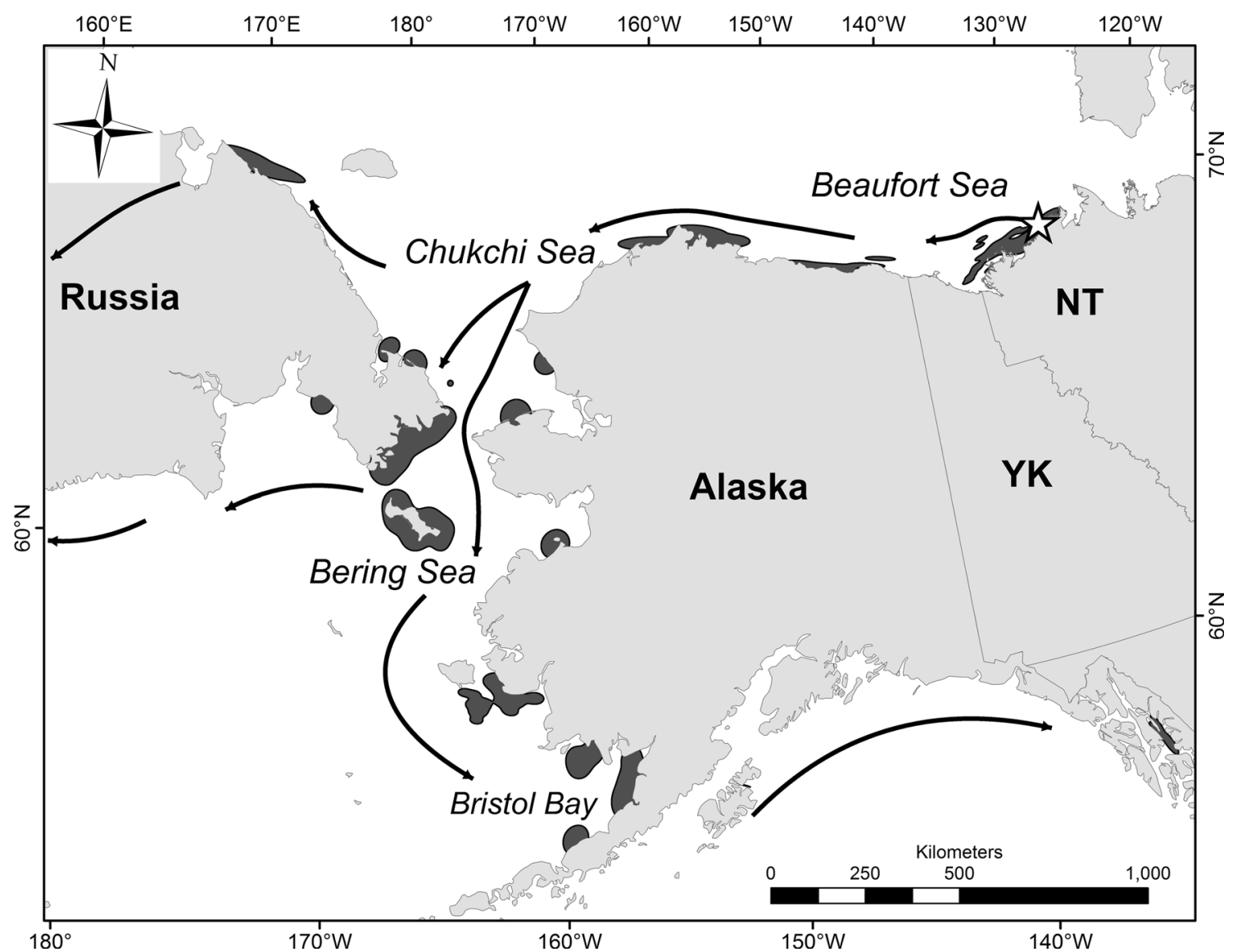

Fig. 2 Fall migration of long-tailed ducks (Clangula hyemalis; $n=57$ ) that molted in McKinley Bay, Northwest Territories, Canada (represented by the star). Arrows represent the general direction of

The second-year data from birds were sparse as the battery power from the transmitters that were still functioning was low and thus provided infrequent quality locations. Of the birds that returned to McKinley Bay to molt with discernible start dates for the second fall migration, one female left McKinley Bay 6 days later in the second year, another female left 14 days later, and a male left 1 day earlier. Fall migration commenced 36 days earlier for a male and 20 days later for a female that molted off northwestern Alaska in the second year. Some individuals were detected using same staging areas as they did the previous season. However, quantifiable comparisons were not possible as most remaining transmitters ceased functioning before migration was complete and location data were too intermittent to confidently determine whether areas were not used.

\section{Winter}

During winter, long-tailed ducks from this study were spread throughout coastal regions of the North Pacific with most ducks concentrated around Kamchatka Peninsula, Russia, and southwestern Alaska (Fig. 3). The winter period for long-tailed migration, and the darker polygons represent major staging areas (95\% kernel density estimate volume contour) along the migration route. NT Northwest Territories, YK Yukon

ducks began November $14 \pm 18$ days $(n=28)$ and lasted $155 \pm 22$ days $(n=15)$. Distances between consecutive locations were relatively short for most ducks during the winter season, and total distance travelled was $989 \pm 441 \mathrm{~km}$ $(n=18$; Table 2$)$. The winter range was $6232 \pm 9894 \mathrm{~km}^{2}$ $(n=18)$, but when three individuals with winter ranges $\geq 10,000 \mathrm{~km}^{2}$ were excluded from the analysis, the winter range was considerably smaller: $2387 \pm 2029 \mathrm{~km}^{2}(n=15)$. Three individuals had transmitters that provided locations into the second winter season, allowing us to calculate distances between mean winter locations (i.e., fidelity) for those individuals: 290, 16, and $2 \mathrm{~km}$. There was possibly a fourth individual with second-winter data, located off South Korea, but we did not have multiple location data in the second year to confirm whether the bird had arrived at its winter location or whether it was still migrating (Fig. 3).

\section{Spring migration}

During spring migration, birds generally followed coastlines to breeding areas (Fig. 4). Based on inland location data during spring migration, we determined that one 


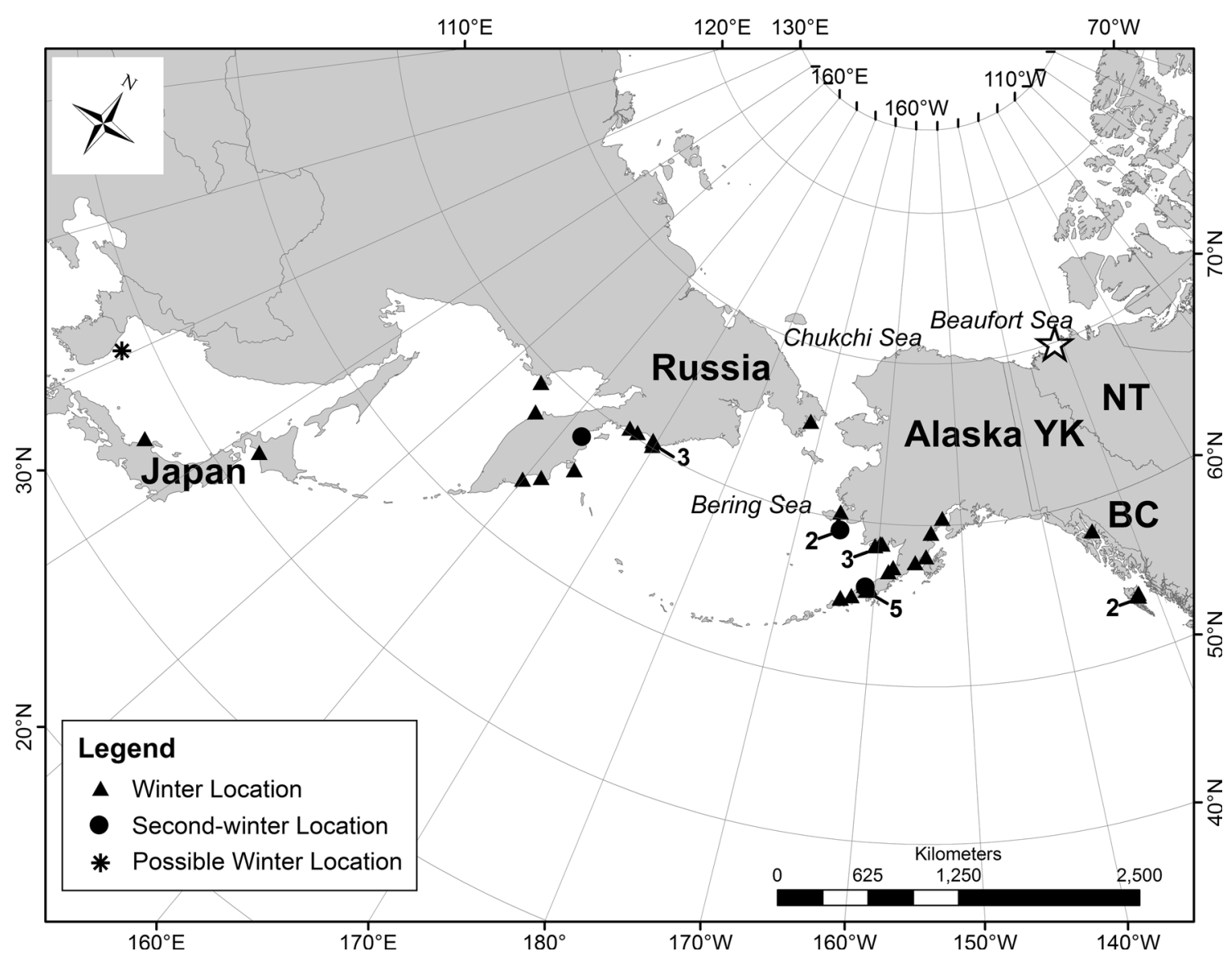

Fig. 3 Winter locations of long-tailed ducks (Clangula hyemalis; $n=34$ ) marked with satellite transmitters at McKinley Bay, Northwest Territories, Canada (represented by star). Circles represent locations for birds with two consecutive winter seasons of location data. The asterisk represents a possible winter location. Numbers of

Table 2 Distances (mean \pm standard deviation) travelled by longtailed ducks (Clangula hyemalis) marked with satellite transmitters at McKinley Bay, Northwest Territories, Canada, in 2009 and 2010

\begin{tabular}{lcr}
\hline Season & Distance travelled $(\mathrm{km})$ & $N$ \\
\hline Fall migration & $3293 \pm 1324$ & 35 \\
Winter & $989 \pm 441$ & 18 \\
Spring migration & $3216 \pm 682$ & 12 \\
Breeding & $28 \pm 21$ & 6 \\
Molt migration & $56 \pm 104$ & 8 \\
Molt & $78 \pm 49$ & 6 \\
\hline
\end{tabular}

Distances reported for the breeding season are for females only

female migrated overland from Norton Sound, Alaska, to a breeding area in Northwest Territories (Fig. 4); perhaps, a second female migrated over land, but it had only one inland location between leaving Norton Sound and arriving at the breeding area. The onset of spring migration was April $21 \pm 15$ days $(n=15)$ and lasted $55 \pm 12$ days $(n=10)$, and total distance travelled was $3216 \pm 683 \mathrm{~km}$ locations, both first winter and second winter, are displayed on the map where it is difficult to visually ascertain how many locations are in particular areas. $B C$ British Columbia; NT Northwest Territories, $Y K$ Yukon

$(n=12$; Table 2). Although most of the birds headed to North America, two females migrated westward into the East Siberian Sea (Fig. 4); location data were too intermittent for one of these individuals to determine the exact migration route, but the other individual travelled westward from Chukotka Peninsula along the north Siberian coast.

Spring staging occurred at five locations (Fig. 4). Eight individuals (40\% of all functioning transmitters) staged between Bristol Bay and Yukon-Kuskokwim Delta, arriving April $19 \pm 18$ days and departing May $22 \pm 8$ days; three additional individuals moved through the area but did not stage. Five individuals $(25 \%$ of all functioning transmitters) staged along the Russian coastline between Kamchatka and Chukotka Peninsula, arriving May $5 \pm 12$ days and departing May $23 \pm 5$ days; two more individuals moved through the area without staging. Three individuals (18\% of all functioning transmitters) staged at a small area on the northeastern portion of Chukotka Peninsula, arriving May $27 \pm 11$ days and departing June $7 \pm 9$ days. Four individuals (27\% of all functioning 


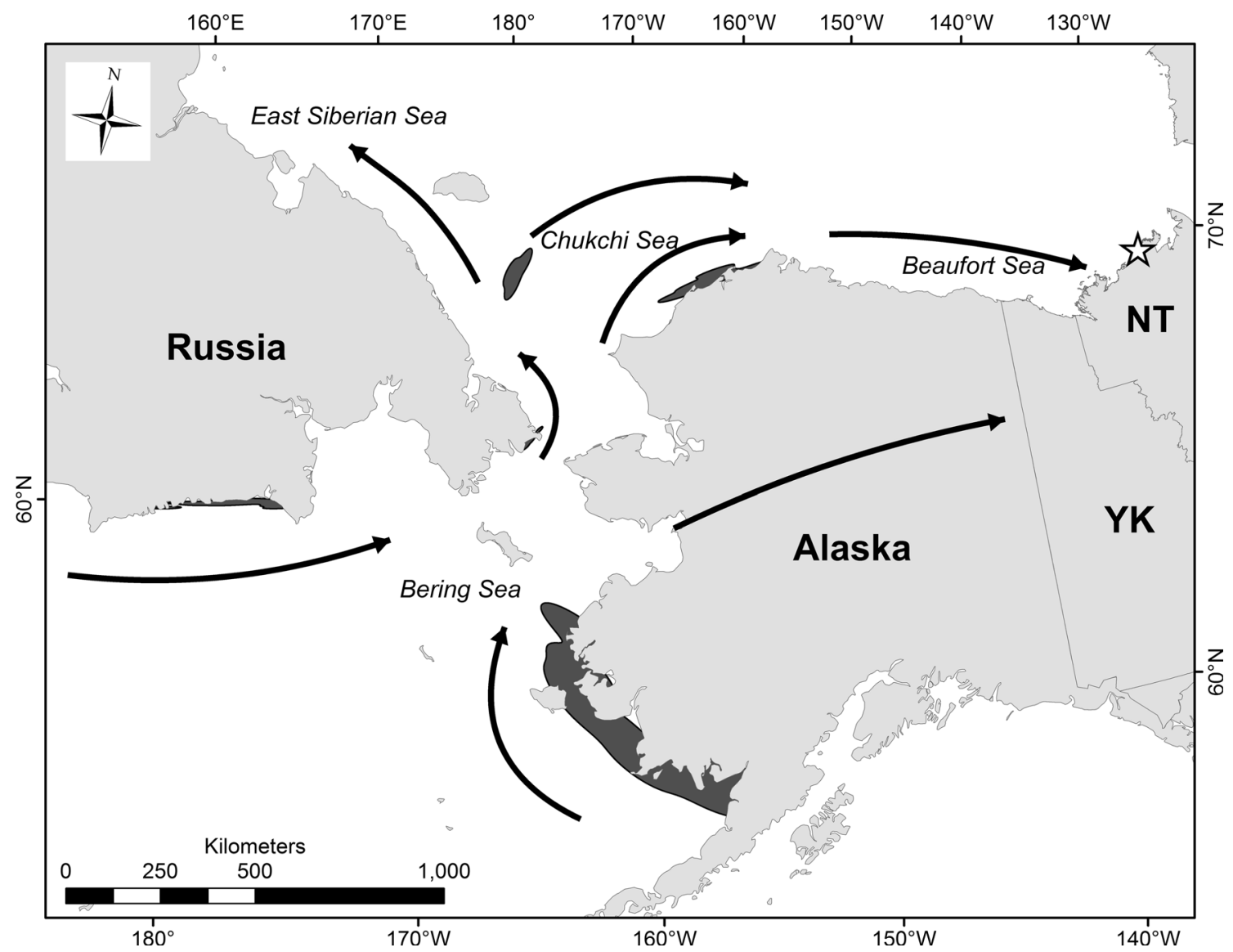

Fig. 4 Spring migration in 2010 and 2011 of long-tailed ducks (Clangula hyemalis; $n=21$ ) marked with satellite transmitters at McKinley Bay, Northwest Territories, Canada (represented by star).

transmitters) staged at a location west of Point Barrow, Alaska, arriving June $5 \pm 9$ days and departing June $17 \pm 9$ days; two more individuals travelled through that area. One individual staged more than $150 \mathrm{~km}$ offshore between Chukotka Peninsula and Wrangel Island, Russia, for approximately 13 days starting around May 28 before migrating eastward through the Beaufort Sea (Fig. 4). No individuals staged in the Beaufort Sea before arriving at breeding destinations, but one individual did stage in the Mackenzie River Delta $\left(68^{\circ} 46^{\prime} \mathrm{N}, 134^{\circ} 10^{\prime} \mathrm{W}\right)$, and one individual staged at Husky Lakes $\left(69^{\circ} 11^{\prime} \mathrm{N}, 131^{\circ} 00^{\prime} \mathrm{W}\right)$, near Tuktoyaktuk Peninsula. Of the six individuals with location data in the Beaufort Sea, the time spent there during spring migration was $5 \pm 2$ days, indicating rapid movements through the area.

\section{Breeding}

Females arrived at breeding areas on June $16 \pm 12$ days $(n=11)$ and remained there for $39 \pm 14$ days $(n=5)$. Two males transmitted during the breeding and second molting period but were not used to calculate dates of onset
Arrows represent the general direction of migration, and the darker areas in the ocean represent major staging areas $(95 \%$ kernel density estimate volume contour) along the migration route

and duration of breeding season because of uncertainty in whether the males actually bred; one male remained near Point Hope, Alaska $\left(68^{\circ} 13^{\prime} \mathrm{N}, 166^{\circ} 04^{\prime} \mathrm{W}\right)$, during the breeding and molting period, and the other was located at McKinley Bay. One female that may or may not have attempted breeding remained in Peard Bay, Alaska $\left(70^{\circ} 50^{\prime} \mathrm{N}, 158^{\circ} 57^{\prime} \mathrm{W}\right)$, through the breeding and molting period; she arrived early July but was never inland and stationary for a period time. There was no clear evidence that the two females that migrated into the East Siberian Sea attempted nesting: One individual was on or very near land on northern Chukotka Peninsula $\left(67^{\circ} 00^{\prime} \mathrm{N}, 172^{\circ} 45^{\prime} \mathrm{W}\right)$ for 10 to 15 days in mid-June, but it was not at that location long enough to determine whether it attempted to nest, and the other individual's transmitter ceased transmitting before the breeding season. The remaining 11 females with functional transmitters bred widely dispersed on the northern portion of the mainland of the Northwest Territories inland as far as $280 \mathrm{~km}$ (Fig. 5). The distance moved by females during the breeding period was $28 \pm 21 \mathrm{~km}$ ( $n=6$; Table 2 ), but we caution the actual distance travelled may be higher than reported as transmitters were 
programmed to provide only a single location every 2-3 days.

\section{Molt migration}

Of the six birds with functioning transmitters and a distinguishable onset date for molt in the second year, only one, a female, had a measurable molt migration period of 4 days beginning on July 23. Three individuals that molted at McKinley Bay, two females and one male, were situated at or near McKinley Bay during the breeding period, so there was no distinguishable molt migration. Another female made the migration from its breeding location to the molt site, McKinley Bay, in 1 transmission cycle, indicating that migration occurred over a period of $<3$ days. One other female commenced molt migration on July 22, but its transmitter ceased functioning before arriving at a molt location. Distance travelled for molt migration was $56 \pm 104 \mathrm{~km}(n=8$; Table 2$)$, which includes five birds that did not have a measurable migration, i.e., distance $=0$.

\section{Molt}

In the second year, four birds molted at McKinley Bay beginning July $29 \pm 2$ days. There were another four birds with location data for the molt period, but there were no large-scale movements from the end of the breeding period, so start date of molt could not be determined. Only two birds had clear start and end dates for molt; they remained at molt locations for 65 and 40 days. Three of the eight individuals with second-year molt location data did not return to McKinley Bay to molt, rather remained near their breeding season location: (a) One female molted in the East Siberia Sea, $2633 \mathrm{~km}$ from McKinley Bay, (b) another female molted at Peard Bay, Alaska, $1045 \mathrm{~km}$ from McKinley Bay, and (c) one male molted near Point Hope, Alaska, $1403 \mathrm{~km}$ from McKinley Bay. The remaining five individuals, one male and four females, were all situated in

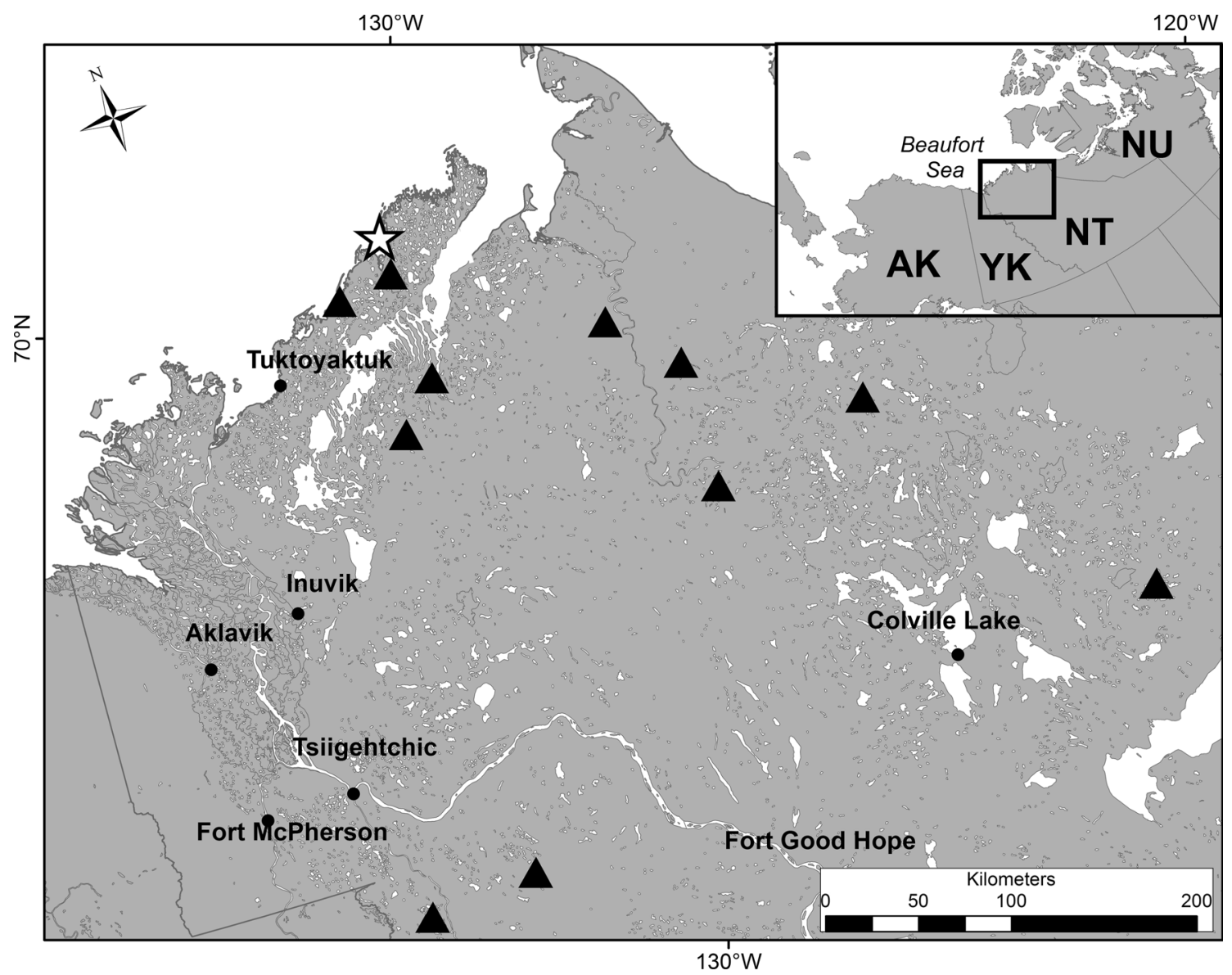

Fig. 5 Breeding locations (represented by triangles) of female longtailed ducks (Clangula hyemalis; $n=11$ ) in Northwest Territories, Canada, in 2010 and 2011; communities of the region are labelled. The star indicates McKinley Bay, the capture and molt site for ducks marked with satellite transmitters for this study. Inset map displays the extent of the larger map in northwestern North America; $A K$ Alaska; NT Northwest Territories; $N U$ Nunavut; $Y K$ Yukon 
the Northwest Territories during the breeding period and used McKinley Bay to molt. Distance moved during the molt period was $78 \pm 49 \mathrm{~km}(n=8$; Table 2$)$, but this period includes time before and after actual molting for birds that remained at the molt location for extended periods, i.e., longer than actual molt time.

\section{Movements in relation to oil and gas lease areas}

During spring migration, no long-tailed ducks were located within the offshore leases of the Alaskan Chukchi Sea, but some ducks staged along the Alaskan coast $<80 \mathrm{~km}$ from those leases (Fig. 6). Ducks used the Chukchi Sea north of Cape Lisburne as early as 28 May, and two birds, a male and a female, spent the breeding and molting seasons in that region. There were few locations of long-tailed ducks in the vicinity of oil and gas leases in both the Alaskan and Canadian Beaufort Sea in the spring and none of the birds staged there during spring migration. Ducks were detected in the Alaskan Beaufort Sea from 7 June to 30 June, and as early as 31 May in the Canadian Beaufort Sea. Two females apparently bred near the coast on the Tuktoyaktuk Peninsula, and one was less than $2 \mathrm{~km}$ from the edge of an onshore significant discovery lease. In addition, one male was situated in and around McKinley Bay during the breeding period, which was used as a harbor and support base for offshore drilling operations from the 1970s to the 1990s (Latour et al. 2008). Unlike spring migration, ducks moved through and staged in the oil and gas leases of the Canadian Beaufort Sea during fall migration (Fig. 7); most were within $50 \mathrm{~km}$ of the coastline at that time, but one went as far as $93 \mathrm{~km}$ offshore. Long-tailed ducks were detected in the Canadian Beaufort Sea as late as 24 October. Similar to the Canadian Beaufort Sea, some ducks staged near the shore $(<50 \mathrm{~km})$ of the Alaskan Beaufort and Chukchi Seas during fall migration in or near oil and gas leases and active drilling platforms (Fig. 6). In Alaska, migrating ducks were detected in the Beaufort and Chukchi Seas from August 30 to October 20. In the winter period, two ducks, a male and female, were near oil and gas leases in Cook Inlet, Alaska.

\section{Discussion}

Understanding migratory connectivity remains a challenge for conservation, especially for species that migrate long distances and live part of their lives in remote locations (Webster et al. 2002; Hobson 2008). However, conservation actions for migratory species can only be most effective with a full understanding of their migratory patterns. Recent tracking studies, including this one, have revealed migratory pathways, distances and speeds travelled, key migratory stopover points, associations between breeding and wintering areas, fidelity to specific areas during annual migratory cycles, and more (Butler et al. 1998; Oppel et al. 2008; Bridge et al. 2015). Although isotope and genetic analysis may provide a cost-effective means to identify broad low-resolution associations among various areas used during migration, data from tracking technology, such as satellite transmitters, are required for precise information on locations used, fine-scale movements, and timing of migration (Hobson 2008; Bridge et al. 2015).

With the use of satellite telemetry, we were able to characterize spatiotemporal use of habitat by long-tailed ducks and thus, generally, met the objectives and predictions of this study. We determined that long-tailed ducks from the western Canadian Arctic travelled through the Beaufort and Chukchi Seas to winter areas in the North Pacific in Asia and North America. Both fall and spring migrations were characterized by bouts of rapid movement through some areas followed by relatively stationary periods, i.e., staging. In addition, we found that ducks from this study did use some, but not all, of the same staging areas for both spring and fall migrations. Although second-year data were sparse, we found that long-tailed ducks from this study may exhibit a lower degree of fidelity to molt sites and perhaps breeding areas than other species of sea ducks (e.g., king eiders; Phillips and Powell 2006). There was some evidence to suggest fidelity to winter sites, but there were too few birds $(n=3)$ to conclusively ascertain winter site fidelity. Finally, we certainly found some overlap between habitats used by long-tailed ducks and areas with potential for offshore oil and gas development, thereby potentially putting long-tailed ducks at risk.

Long-tailed ducks tracked for this project all migrated westward along the Arctic coastline to wintering areas in northeastern Asia, Alaska, and northern British Columbia after molting. Similarly, three long-tailed ducks tagged during the breeding period on central Victoria Island, Northwest Territories, all migrated westward to winter (Dickson unpublished data). To date, no long-tailed ducks marked on wintering areas on the Atlantic coast or Great Lakes have bred west of the Kent Peninsula, Nunavut, Canada (Mallory et al. 2006; Sea Duck Joint Venture 2015a). Based on these results, and similar to king and common eiders (Mehl et al. 2004; Dickson 2012a, b), the boundary between breeding areas for Pacific and Atlantic populations of long-tailed ducks is likely well east of the Beaufort Sea somewhere in central Arctic Canada.

Clearly, the Canadian Beaufort Sea is important for long-tailed ducks that breed and molt in the Northwest Territories. Nearly half of the tagged ducks that molted in McKinley Bay staged from early September to early October in the Canadian Beaufort Sea before migrating to Alaska and beyond. Although none of the returning ducks 


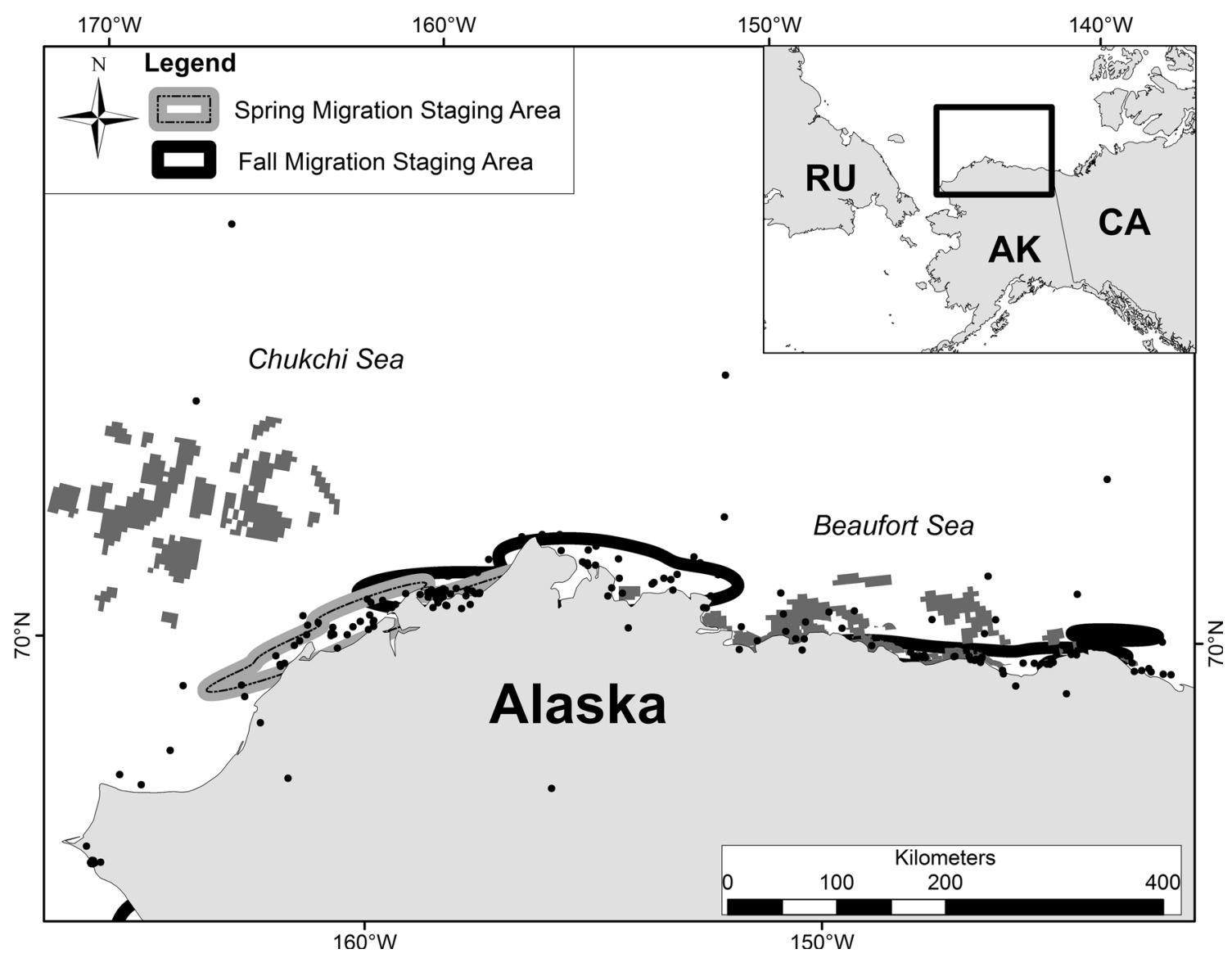

Fig. 6 Locations of long-tailed ducks (Clangula hyemalis) marked with satellite transmitters at McKinley Bay, Northwest Territories, Canada, in relation to oil and gas leases of the Alaskan Beaufort and Chukchi Seas. Darkened polygons represent State and Federal offshore leases. The black circles represent locations of individuals

staged in the Canadian Beaufort Sea during spring migration, some individuals bred or were situated near the coast during the breeding period. Based on this study's results, long-tailed ducks could be encountered in the Canadian Beaufort Sea near the mainland coast, anytime from late May to late October. Past studies have also documented the importance of the Canadian Beaufort Sea to long-tailed ducks over a similar time period (Alexander et al. 1988, 1997; Dickson and Gilchrist 2002). Although only $18 \%$ of birds from the McKinley Bay molting area staged in the Alaskan Beaufort and Chukchi Seas along the Alaskan north coast during fall migration, an additional $35 \%$ were detected in the area. Furthermore, it is likely some of the ducks that were not detected along the Alaskan north coast, but were detected further westward did travel along the coast; these birds likely moved through in less than one transmission cycle. This stretch of coastline is also of key importance to long-tailed ducks breeding and molting in northern Alaska with nearly 90,000 long-tailed ducks using this area in some years (Lacroix et al. 2003; in the region from September 2009 to October 2011. The thick lines delineate spring and fall staging areas $(95 \%$ kernel density estimate volume contour). Inset map displays the extent of the larger map; $A K$ Alaska, $C A$ Canada, $R U$ Russia

Lysne et al. 2004; Stehn et al. 2013). West of the Beaufort Sea, long-tailed ducks on fall migration staged primarily off Chukotka Peninsula, St Lawrence Island, and Bristol Bay; these areas are also important post-breeding locations for long-tailed ducks breeding at the Yukon-Kuskokwim Delta (Petersen et al. 2003). Although second-year migration data were sparse, there was evidence to suggest at least some of the fall migration staging areas were used by the same individuals year after year. In addition, king and common eiders use these same staging areas during fall and molt migration, further highlighting the importance of these regions to sea ducks (Petersen and Flint 2002; Phillips et al. 2006; Dickson 2012a, b).

In winter, long-tailed ducks from this study were widely dispersed from South Korea and southern Canada to the polynya off Chukotka Peninsula in the northern Bering Sea. Long-tailed ducks marked during breeding on YukonKuskokwim Delta were similarly distributed in winter (Petersen et al. 2003), and this winter distribution pattern is similar to that of king eiders from northern Alaska and the 


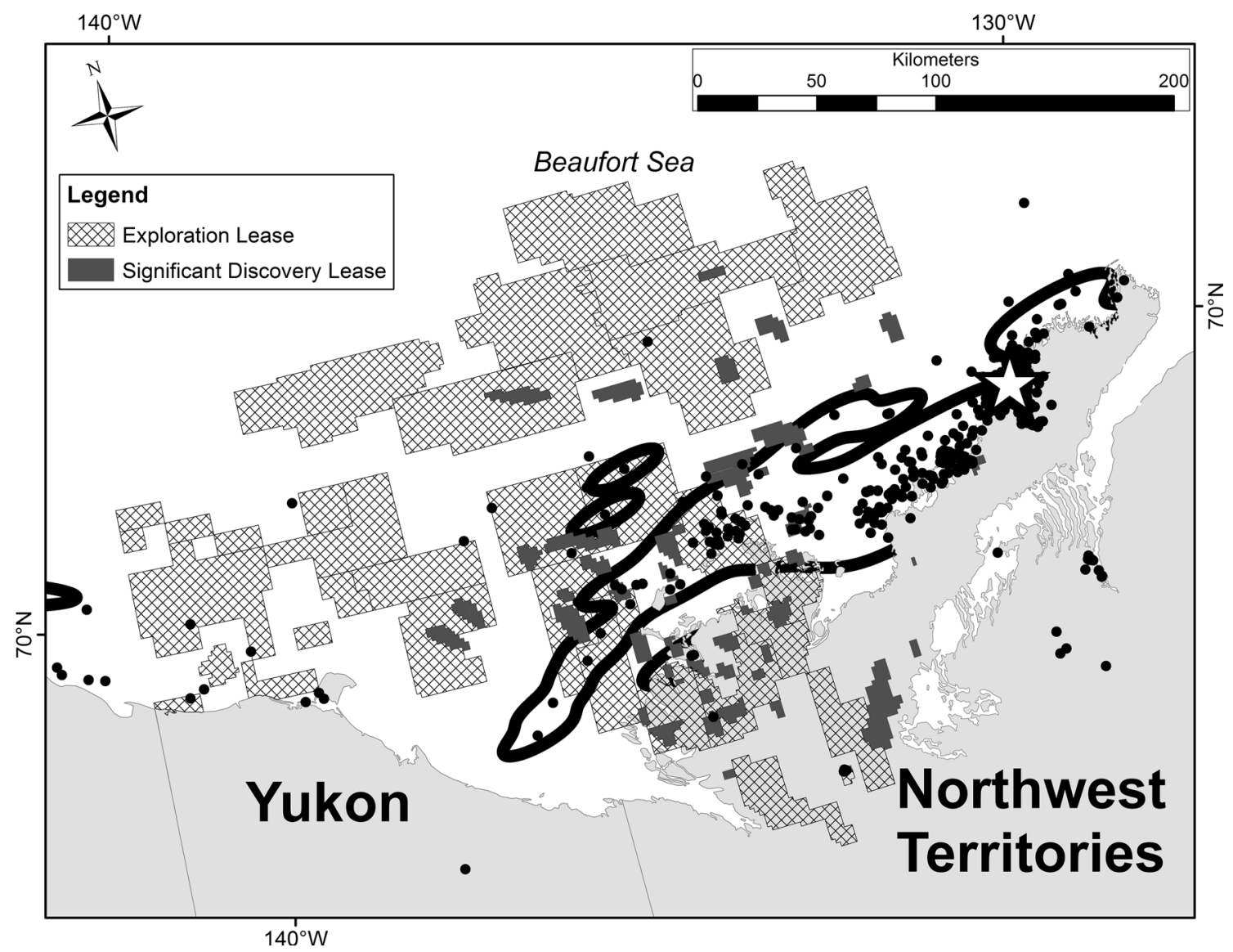

Fig. 7 Locations of long-tailed ducks (Clangula hyemalis) in relation to oil and gas leases of the Canadian Beaufort Sea. Birds were marked with satellite transmitters at McKinley Bay, Northwest Territories, Canada (represented by star). The black circles represent locations of

western Canadian Arctic (Phillips et al. 2006; Oppel et al. 2008; Dickson 2012a; Bentzen and Powell 2015). This distribution is markedly different from the highly clumped distribution of common and spectacled eiders, which would be much more vulnerable to winter habitat loss than longtailed ducks or king eiders (Petersen et al. 1999; Petersen and Flint 2002; Dickson 2012b). Although there were only three birds with locations for two consecutive winters, all three birds generally used the same sites between years, similar to long-tailed ducks wintering in the Great Lakes and on the Atlantic coast (Sea Duck Joint Venture 2015b).

The main staging areas during spring migration were between Bristol Bay and Yukon-Kuskokwim Delta, the coastline between Kamchatka and Chukotka Peninsula, and the area west of Point Barrow in the Alaskan Chukchi Sea. Because sample size during spring was small $(n=15$ functioning transmitters), it is possible some spring migration staging areas and breeding areas were not detected. For instance, aerial surveys from the 1980s and 1990s documented large numbers of long-tailed ducks staging in the southeast Beaufort Sea north of Tuktoyaktuk individuals in the region from August 2009 to October 2011. The thick dark lines in the Beaufort Sea delineate the fall staging areas (95\% kernel density estimate volume contour)

Peninsula and Cape Bathurst in the spring (Alexander et al. 1997; Dickson and Gilchrist 2002). However, of the 12 individuals tracked to mainland western Canadian Arctic for the breeding period, none staged in the Beaufort Sea during spring migration. Long-tailed ducks observed in previous surveys were perhaps ducks en route to breeding areas farther north and east of the Beaufort Sea, such as Banks and Victoria islands in the Arctic Archipelago of Canada. However, it is also possible that migration patterns have changed since surveys were last conducted. To get a more complete understanding of seasonal movement patterns of long-tailed ducks through the Beaufort Sea, satellite transmitters should be deployed on birds from breeding areas in central Arctic Canada; this would not only improve our knowledge of key areas for the species, but also aid in delineation of the boundary or area of overlap between Atlantic and Pacific populations.

This study's results suggest that long-tailed ducks' fidelity to molt locations depends somewhat on where they spend the breeding season. Marked birds, one male and four females, that were in the Northwest Territories during 
the breeding season and had second-year molt data all returned to McKinley Bay to molt, a migration $\leq 280 \mathrm{~km}$. Similarly, those ducks, one male and two females, that were in Russia and Alaska during the breeding period in the second year stayed roughly at those locations to molt rather than migrate over $1000 \mathrm{~km}$ to the McKinley Bay molt site used the previous year. Petersen et al. (2003) found that female long-tailed ducks breeding on the Yukon-Kuskokwim Delta all molted within $650 \mathrm{~km}$ of the breeding site. If long-tailed ducks tend to molt relatively close to their breeding sites, then the individuals situated in Alaska and Russia in the second year were in a completely different breeding area than they had used the previous year when they were most likely near McKinley Bay. This plasticity to molt sites, and perhaps breeding sites, was unexpected as other sea ducks display a high degree of fidelity to breeding and molt sites (Flint et al. 2000; Phillips and Powell 2006).

During spring migration, long-tailed ducks may be less vulnerable to impacts of oil and gas development in the Beaufort Sea than common and king eiders, which stage there for three to four weeks (Dickson and Smith 2013). However, some long-tailed ducks bred near the coast, and unlike most eiders from the region (Dickson 2012a, b), long-tailed ducks molted and staged in the fall in the southeast Beaufort region. Based on this study's results, long-tailed ducks are in the Canadian Beaufort Sea from late May to late October, a period of 5 months, and potentially exposed to impacts of oil and gas development in the region throughout nesting, molting, and the initial part of fall migration. However, most long-tailed ducks are at risk from late July to early October when located along the coast. McKinley Bay, the capture and molt site for ducks from this study, was used as a harbor and support base for offshore drilling operations from the 1970s to the 1990s and development and increased activity may occur there should oil and gas development take place in the region (Latour et al. 2008). Based solely on potential exposure time, long-tailed ducks breeding and molting in the western Canadian Arctic would be most at risk from oil and gas development activities in that region.

Long-tailed ducks from the western Canadian Arctic are certainly vulnerable to impacts from oil and gas activities outside of the Canadian Beaufort Sea as well. Long-tailed ducks from this study moved through or near leases in the Alaskan Beaufort and Chukchi Seas but spent less time there than the Canadian Beaufort Sea. Based on this study's results, long-tailed ducks migrating to and from the western Canadian Arctic could be in the Alaskan Beaufort and Chukchi Seas in or near leases from late May until late June and from late August until the end of October. In addition, two individuals spent the second summer along the Alaskan coast of the Chukchi Sea as opposed to returning to the western Canadian Arctic. The Beaufort and Chukchi Seas of Alaska are also known to be important areas for long-tailed ducks from other areas of the Arctic, as well as other species of sea ducks (Petersen and Flint 2002; Lacroix et al. 2003; Oppel et al. 2009). The Chukotka Peninsula of Russia, a major staging area for longtailed ducks from this study along with other populations of sea ducks (Petersen et al. 2003; Oppel et al. 2008; Dickson 2012a, b), also has large reserves of oil and gas that could adversely affect sea ducks if extracted. Finally, some longtailed ducks, such as the two that wintered in Cook Inlet in southern Alaska, may also be vulnerable to oil and gas activities during the winter period.

It is important to consider that the aforementioned patterns of migration specifically pertain to long-tailed ducks from coastal and mainland areas of the Northwest Territories. Timing of migration and areas used by long-tailed ducks from Alaska and further east and north in the Canadian Arctic may differ. Another important consideration is that winds and currents may carry oil and other pollutants long distances in a discharge event, potentially putting sea ducks at risk even though they may be some distance from the actual point source. Ducks may also be vulnerable from activities associated with oil and gas development outside of the lease areas, such as shipping. Time spent at particular areas during the annual migratory cycle should not be the sole consideration when determining relative importance of areas. Disruptions to any areas along migration routes or in the vicinity of breeding, molt, or winter areas could have lasting impacts on the population, and although they may spend less time at particular areas along migration, those areas may prove important stopover points for rest and refueling (van Gils et al. 2005). Although we found no evidence of annual variation in timing of migratory periods, weather likely does affect timing of initiation and duration of migration (Richardson 1978). Should season dates consistently shift as a result of changing climate, it is possible the timing of migratory periods presented in this study could also change (Gordo 2007).

Long-tailed ducks from the western Canadian Arctic may be less vulnerable to anthropogenic and environmental perturbations than eiders breeding and wintering in the same areas (e.g., Petersen et al. 1999; Petersen and Flint 2002; Oppel et al. 2008). Firstly, long-tailed ducks from the western Canadian Arctic are more widely distributed than eiders during winter, leaving the population as a whole less susceptible to any single event at that time of year, such as an oil spill. Furthermore, long-tailed ducks from this study wintered in similar locations as individuals that bred on the Yukon-Kuskokwim Delta, Alaska, likely allowing for gene flow and, in turn, greater adaptability to change (Webster et al. 2002; Petersen et al. 2003). In addition, three females 
(21\%) did not return to Canada to breed or molt the following year, which may be an indication that females of this species are less philopatric than other sea duck species (e.g., Savard and Eadie 1989; Smith et al. 2000; Phillips and Powell 2006). Long-tailed ducks found in the western Canadian Arctic should be considered part of a Pacific population that could be influenced by events throughout the North Pacific over multiple jurisdictions (Flint 2013). Based on their annual migration patterns, effective conservation of long-tailed ducks may require cooperation among Canada, the USA, Russia, and other Asian countries, such as Japan and South Korea.

Acknowledgments This study was funded by Canadian Wildlife Service, ConocoPhillips (Canada and USA), Sea Duck Joint Venture, and US Fish and Wildlife Service. Molly Kirk, Dennis Marks, and Lisa Pirie assisted with the capture of ducks and field operations. Chuck Gruben, a guide and outfitter from Tuktoyaktuk, was hired as a boat operator and for his expertise on local conditions for both years of the field operations. Veterinarian Pam Tuomi performed the surgeries, and all birds were handled under Environment Canada Animal Care Committee protocol \#EC-PN-10-022. Garnet Raven assisted with data preparation by filtering the spatial data to omit unlikely locations. Tuktoyaktuk Hunters and Trappers Committee supported this project.

\section{Compliance with ethical standards}

Ethical approval All applicable International, National and/or Institutional Guidelines for the care and use of animals were followed.

Open Access This article is distributed under the terms of the Creative Commons Attribution 4.0 International License (http://crea tivecommons.org/licenses/by/4.0/), which permits unrestricted use, distribution, and reproduction in any medium, provided you give appropriate credit to the original author(s) and the source, provide a link to the Creative Commons license, and indicate if changes were made.

\section{References}

Alexander SA, Barry TW, Dickson DL, Prus HD, Smyth KE (1988) Key areas for birds in coastal regions of the Canadian Beaufort Sea. Environment Canada, Canadian Wildlife Service, Edmonton, Alberta

Alexander SA, Dickson DL, Westover SE (1997) Spring migration of eiders and other waterbirds in offshore areas of the western Arctic. In: Dickson DL (ed) King and common eiders of the western Canadian Arctic. Occasional paper no. 94. Canadian Wildlife Service, Ottawa, Ontario, Canada, pp 6-20

Bentzen RL, Powell AN (2015) Dispersal, movements and site fidelity of post-fledging King Eiders Somateria spectabilis and their attendant females. Ibis 157:133-146

Beyer HL (2012) Geospatial Modelling Environment (Version 0.7.2.1). (Software). http://www.spatialecology.com/gme

Bowman TD, Silverman ED, Gilliand SG, Leirness JB (2015) Status and trends of North American sea ducks: Reinforcing the need for better monitoring. In: Savard J-PL, Derksen DV, Esler D, Eadie JM (eds) Ecology and conservation of North American sea ducks. Stud Avian Biol-Ser, vol 46. CRC Press, Boca Raton, FL, pp 1-28
Breault AM, Cheng KM (1990) Use of submerged mist nets to capture diving birds. J Field Ornithol 61:328-330

Bridge ES, Kelly JF, Xiao X, Batbayar N, Natsagdorj T, Hill NJ, Takekawa JY, Hawkes LA, Bishop CM, Butler PJ, Newman SH (2015) Stable isotopes suggest low site fidelity in bar-headed geese (Anser indicus) in Mongolia: implications for disease transmission. Waterbirds 38:123-220

Butler PJ, Woakes AJ, Bishop CM (1998) Behaviour and physiology of Svalbard Barnacle Geese Branta leucopsis during their autumn migration. J Avian Biol 29:536-545

Bureau of Ocean Energy Management (2013) Active leases up through Sale 193. http://www.boem.gov/Oil-and-Gas-EnergyProgram/Mapping-and-Data/Alaska.aspx\#GIStable. Accessed 11 July 2013

Chapin FS, Shaver GR, Giblin AE, Nadelhoffer KJ, Laundre JA (1995) Responses of Arctic tundra to experimental and observed changes in climate. Ecology 76:694-711

Corbett JJ, Lack DA, Winebrake JJ, Harder S, Silberman JA, Gold M (2010) Arctic shipping emissions inventories and future scenarios. Atmos Chem Phys 10:9689-9704

Day RH, Rose JR, Prichard AK, Streever B (2015) Effects of gas flaring on the behavior of night-migrating birds at an artificial oil-production Island, Arctic Alaska. Arctic 68:367-379

de la Cruz SEW, Takekawa JY, Wilson MT, Nysewander DR, Evenson JR, Esler D, Boyd WS, Ward DH (2009) Spring migration routes and chronology of surf scoters (Melanitta perspicillata): a synthesis of Pacific coast studies. Can J Zool 87:1069-1086

Dickey MH, Gauthier G, Cadieux MC (2008) Climatic effects on the breeding phenology and reproductive success of an arcticnesting goose species. Glob Change Biol 14:1973-1985

Dickson DL (2012a) Seasonal Movement of King Eiders Breeding in Western Arctic Canada and Northern Alaska. Technical Report Series Number 520. Canadian Wildlife Service, Edmonton, Alberta, Canada

Dickson DL (2012b) Seasonal Movement of Pacific Common Eiders Breeding in Arctic Canada. Technical Report Series Number 521. Canadian Wildlife Service, Edmonton, Alberta, Canada

Dickson DL, Gilchrist HG (2002) Status of marine birds of the southeastern Beaufort Sea. Arctic 55:46-58

Dickson DL, Smith PA (2013) Habitat used by common and king eiders in spring in the southeast Beaufort Sea and overlap with resource exploration. J Wildlife Manage 77:777-790

Douglas DC, Weinzierl R, C Davidson S, Kays R, Wikelski M, Bohrer G (2012) Moderating Argos location errors in animal tracking data. Methods Ecol Evol 3:999-1007

Flint PL (2013) Changes in size and trends of North American sea duck populations associated with North Pacific oceanic regime shifts. Mar Biol 160:59-65

Flint PL, Petersen MR, Dau CP, Hines JE, Nichols JD (2000) Annual survival and site fidelity of Steller's eiders molting along the Alaska Peninsula. J Wildlife Manage 64:261-268

Gautier DL, Bird KJ, Charpentier RR, Grantz A, Houseknecht DW, Klett TR, Moore TE, Pitman JK, Schenk CJ, Schuenemeyer JH, Sørensen K, Tennyson ME, Valin ZC, Wandrey CJ (2009) Assessment of undiscovered oil and gas in the arctic. Science 324:1175-1179

Gordo O (2007) Why are bird migration dates shifting? A review of weather and climate effects on avian migratory phenology. Clim Res 35:37-58

Government of Canada (2013) Oil and gas rights digital files. http:// www.aadnc-aandc.gc.ca/eng/1100100036298/1100100036301, Accessed 4 July 2013

Greenwood PJ (1980) Mating systems, philopatry and dispersal in birds and mammals. Anim Behav 28:1140-1162 
Guillemette M, Pelletier D, Grandbois JM, Butler PJ (2007) Flightlessness and the energetic cost of wing molt in a large sea duck. Ecology 88:2936-2945

Hinzman LD et al (2005) Evidence and implications of recent climate change in Northern Alaska and other Arctic regions. Clim Change 72:251-298

Hobson KA (2008) Using endogenous and exogenous markers in bird conservation. Bird Conserv Int 18:S174-S199

Korschgen CE, Kenow KP, Gendron-Fitzpatrick A, Green WL, Joshua Dein F (1996) Implanting intra-abdominal radiotransmitters with external whip antennas in ducks. J Wildlife Manage 60:132-137

Lacroix DL, Lanctot RB, Reed JA, McDonald TL (2003) Effect of underwater seismic surveys on molting male Long-tailed Ducks in the Beaufort Sea, Alaska. Can J Zool 81:1862-1875

Latour PB et al. (2008) Key migratory bird terrestrial habitat sites in the Northwest Territories and Nunavut. Occasional paper number 114. 3rd edn., Canadian Wildlife Service, Yellowknife, Northwest Territories, Canada

Lysne LA, Mallek EJ, Dau CP (2004) Near shore surveys of Alaska's Arctic coast, 1999-2003. In: U. S. fish and wildlife service, migratory bird management, waterfowl branch, Fairbanks, Alaska, USA

Mallory ML, Akearok J, North NR, Weseloh DV, Lair S (2006) Movements of long-tailed ducks wintering on lake Ontario to breeding areas in Nunavut, Canada. Wilson $\mathbf{J}$ Ornithol 118:494-501

Mather DD, Esler D (1999) Evaluation of bursal depth as an indicator of age class of harlequin ducks. J Field Ornithol 70:200-205

McKinnon L, Picotin M, Bolduc E, Juillet C, Bêty J (2012) Timing of breeding, peak food availability, and effects of mismatch on chick growth in birds nesting in the High Arctic. Can J Zool 90:961-971

Mehl KR, Alisauskas RT, Hobson KA, Kellett DK (2004) To winter east or west? Heterogeneity in winter philopatry in a centralarctic population of King Eiders. Condor 106:241-251

Mulcahy DM, Esler D (1999) Surgical and immediate postrelease mortality of harlequin ducks (Histrionicus histrionicus) implanted with abdominal radio transmitters with percutaneous antennae. J Zoo Wildlife Med 30:397-401

Nolet BA, Bauer S, Feige N, Kokorev YI, Popov IY, Ebbinge BS (2013) Faltering lemming cycles reduce productivity and population size of a migratory Arctic goose species. J Anim Ecol 82:804-813

Oppel S, Powel AN, Dickson DL (2008) Timing and distance of king eider migration and winter movements. Condor 110:296-305

Oppel S, Dickson DL, Powell AN (2009) International importance of the eastern Chukchi Sea as a staging area for migrating king eiders. Polar Biol 32:775-783

Petersen MR, Flint PL (2002) Population structure of Pacific Common Eiders breeding in Alaska. Condor 104:780-787
Petersen MR, Larned WW, Douglas DC (1999) At-sea distribution of spectacled eiders: a 120-year-old mystery resolved. Auk 116:1009-1020

Petersen MR, McCaffery BJ, Flint PL (2003) Post-breeding distribution of Long-tailed ducks Clangula hyemalis from the YukonKuskokwim Delta, Alaska. Wildfowl 54:103-113

Phillips LM, Powell AN (2006) Evidence for wing molt and breeding site fidelity in King Eiders. Waterbirds 29:148-153

Phillips LM, Powell AN, Rexstad EA (2006) Large-scale movements and habitat characteristics of king eiders throughout the nonbreeding period. Condor 108:887-900

Richardson WJ (1978) Timing and amount of bird migration in relation to weather: a review. Oikos 30:224-272

Robertson GJ, Savard J-PL (2002) Long-tailed Duck (Clangula hyemalis). In: The Birds of North America Online A. Poole, Ed. http://bna.birds.cornell.edu/bna/species/651doi:10.2173/bna.651. Accessed 18 July 2012

Savard J-PL, Eadie JM (1989) Survival and breeding philopatry in Barrow's and common goldeneyes. Condor 91:198-203

Sea Duck Joint Venture (2015a) Long-tailed Duck (Oldsquaw) Clangula hyemalis. http://seaduckjv.org/meet-the-sea-ducks/ long-tailed-duck-oldsquaw/, Accessed 12 February 2016

Sea Duck Joint Venture (2015b) Atlantic and Great Lakes sea duck migration study: progress report June 2015. http://seaduckjv.org/ science-resources/atlantic-and-great-lakes-sea-duck-migrationstudy/. Accessed 12 February 2016

Smith CM, Cooke F, Robertson GJ, Goudie RI, Boyd WS (2000) Long-term pair bonds in Harlequin Ducks. Condor 102:201-205

State of Alaska (2013) Alaska Statewide Active Lease Boundaries. http://dog.dnr.alaska.gov/GIS/GISDataFiles.htm. Accessed 11 July 2013

Stehn RA, Larned WW, Platte RM (2013) Analysis of aerial survey indices monitoring waterbird population of the Arctic Coastal Plain, Alaska, 1986-2012. In: U. S. fish and wildlife service, migratory bird management, waterfowl branch, Anchorage, Alaska, USA

van Gils JA, Battley PF, Piersma T, Drent R (2005) Reinterpretation of gizzard sizes of red knots world-wide emphasises overriding importance of prey quality at migratory stopover sites. Proc Roy Soc Lond B Bio 272:2609-2618

Visser ME, Both C (2005) Shifts in phenology due to global climate change: the need for a yardstick. Proc Roy Soc Lond B Bio 272:2561-2569

Webster MS, Marra PP, Haig SM, Bensch S, Holmes RT (2002) Links between worlds: unraveling migratory connectivity. Trends Ecol Evol 17:76-83

Zabanbark A, Lobkovsky LI (2015) Circumpolar oil-and-gas-bearing basins of the arctic part of the North American continent. Oceanology 55:750-759 